\title{
Viticulture in southwest Germany under climate change conditions
}

\author{
Paul A. Neumann*, Andreas Matzarakis \\ Meteorological Institute, Albert-Ludwigs-University Freiburg, Werthmannstr. 10, 79085 Freiburg, Germany
}

\begin{abstract}
We estimated changes in viticulture conditions over the 21st century in BadenWürttemberg, southwest Germany, using scenario runs of 3 regional climate models for 19611990, 2021-2050 and 2071-2100. The scenario runs were compared and validated with local observational data. By applying the Huglin Index, possible expansions of areas suitable for viticulture, as well as suitable grape varieties for the region, were determined. Optimal grape varieties are changing to those more suitable to a warmer climate. This development was found in all examined simulation runs.
\end{abstract}

KEY WORDS: Viticulture · Southwest Germany $\cdot$ Huglin Index · REMO $\cdot$ CLM $\cdot$ WETTREG

\section{INTRODUCTION}

Baden and Württemberg - located in the Federal State of Baden-Württemberg - are 2 of the major areas for viticulture in Germany (Fig. 1). Although the cultivation area used for viticulture comprises only $1.7 \%$ of all agricultural areas in Baden-Württemberg (SLBW 2010), it contributes significantly to the earnings from the agricultural sector. In 2005 and 2006, the earnings per hectare were 10 times higher than broadacre crops (BMELV 2007) in this region, which highlights the importance of viticulture in the agricultural sector of Baden-Württemberg.

Under changing climate conditions, visible alterations with effects on viticulture have already been observed in some regions of the world (e.g. Jones \& Davis 2000, Duchêne \& Schneider 2005, Jones 2005, Laget et al. 2008), for example a lengthening of the growing season, or a tendency toward earlier phenological events such as budbreak and flowering time. Such changes may have already affected viticulture in Baden-Württemberg.

Future changes in the quantity and quality of regional grapevine products are possible, and to be expected (e.g. Jones et al. 2005, Maracchi et al. 2005, Petgen 2007, Mariani et al. 2009) as are further effects on phenological events, such as of their timing (e.g. Schultz et al. 2005, Webb et al. 2007, Duchêne et al.
2010). A possible further climate-related negative effect is an increased occurrence of grapevine diseases and pests (Petgen 2007). Positive aspects are also possible, such as benefits from an increase in atmospheric $\mathrm{CO}_{2}$ (Schultz 2000, Bindi et al. 2001, Moutinho-Pereira et al. 2009), or from possible expansions of suitable areas for viticulture (Maracchi et al. 2005, Stock 2005, Petgen 2007). A survey by Battaglini et al. (2009) shows that winegrape growers are becoming more and more aware of these changes and their potential impacts. Winegrape growers in Germany and France tend to be more concerned about pests, whereas in Italy they tend to be more concerned about the adverse effects caused by increasing drought stress.

According to a report from the IPCC (IPCC 2007), climatic zones will shift toward the North and South Pole. Therefore it is possible, for example that climate, disease and pest conditions in the Italian regions may become typical for South Germany in the future. Changes in the location and extent of areas suitable for viticulture are anticipated for the 21st century (White et al. 2006, Hall \& Jones 2009). Hall \& Jones (2009), for example, expect that Australia will experience a decrease of areas suitable for high quality wines, since viticulture is close to reaching its southern limit on this continent, and there is no land to allow it to migrate further south. In Baden-Württemberg, a possible expansion of suitable areas for viticulture was observed 


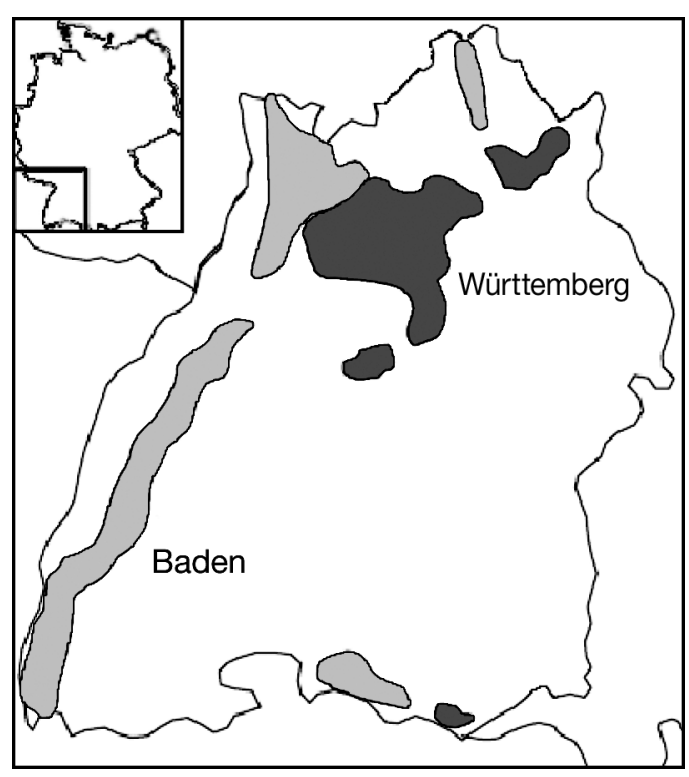

Fig. 1. Most important cultivation areas for viticulture in Baden-Württemberg (Statistisches Bundesamt 2008). Grey: Baden; black: Württemberg

by Stock (2005) using primarily a statistical regional climate model (SRCM) STAR. The scenarios used cover the time period up to 2055, and the main method applied was the Huglin Index (HI, Huglin 1978). The $\mathrm{HI}$ is a commonly used heat summation index to identify suitable areas for different grape varieties, and has been applied in studies of Tonietto \& Carbonneau (2004) as well as Petgen (2007).

In the present study, we examined the possible expansion of suitable areas for different grape varieties, using the HI, for 3 different periods, 1961-1990, 20212050 and 2071-2100. Simulation runs of 2 dynamical regional climate models (DRCMs) were used, the regional model REMO, developed by the Max-PlanckInstitute for Meteorology (Jacob \& Podzun 1997, Jacob et al. 2007), and the Consortium for Small-scale Modeling (COSMO) model in climate limited-area Modelling (CLM) mode (COSMO-CLM or CCLM) (Steppeler et al. 2003, Will et al. 2006). The Special Report on Emissions Scenarios (SRES) A1B and B1 were used for the simulation runs (IPCC 2007). Both emission scenarios are based on the assumption of an integrated world with rapid economic growth. B1 includes reductions in material intensity and the introduction of clean and resourceefficient technologies, together with a change to a more service and information orientated economy. A1B comprises the rapid introduction of new and more efficient technologies together with a balanced use of all energy sources, but is less focused on environmental sustainability than B1. For 2 different climate stations, the model output is validated and compared with simula- tions of the statistical based regional climate model WETTREG of the Max-Planck-Institute for Meteorology (Enke et al. 2006, Spekat et al. 2007). The present study assesses potential changes and examines the possible expansion of those areas suitable for viticulture over a long time scale (up to 2100) according to the 2 DRCMs. In addition, we discuss possible limits of the models used and of the HI.

\section{DATA AND METHODS}

Data from 3 models, 2 dynamical and one statistical, were used to validate the results and were coupled with observation data for verification purposes. To determine values for a particular point, an inverse distance weighted interpolation was applied using the surrounding dynamical model grid points. Areas suitable for viticulture, as well as recommendable grape varieties, were determined using the $\mathrm{HI}$.

\subsection{Model data}

The scenario runs of 3 regional climate models (RCMs) are initialized and forced by the global coupled atmospheric-ocean model ECHAM5/MPI-OM (Marsland et al. 2003, Hagemann et al. 2005, Roeckner et al. 2006):

(1) The 3-dimensional hydrostatic RCM, REMO (Jacob \& Podzun 1997, Jacob et al. 2007), is an atmospheric circulation model that calculates the relevant physical processes dynamically. The model simulation runs used were part of a study of the Federal Environmental Agency (UMPIM 2006), for developing regional climate projections, and they cover most of Germany and the Alps at a resolution of $10 \times 10 \mathrm{~km}$. Two model simulation runs covering the period 2000-2100 (based on SRES A1B and B1) and another covering the period 1961-2000 were available. The parameter 'air temperature $2 \mathrm{~m}$ above ground' is available at a temporal interval of $1 \mathrm{~h}$. For the present study, the area of Baden-Württemberg was examined over the periods 1961-1990, 2021-2050 and 2071-2100; Fig. 2 shows the research area.

(2) The model simulation runs of the CCLM were used in the same way as the simulations of the REMO model. The CCLM (Steppeler et al. 2003, Will et al. 2006) is a non-hydrostatic regional model, which also calculates the relevant physical processes dynamically. The simulation runs used are at a $0.165^{\circ}$ Latitude $x$ Longitude spatial resolution which covers most of Europe. Two model simulation runs for 2000-2100, one based on SRES A1B, one based on SRES B1, and another model simulation run for 1961-2000 were avail- 
able. All simulation runs available for the study were calculated by the Max-Planck-Institute for Meteorology. The parameter 'air temperature $2 \mathrm{~m}$ above ground' is available at a resolution of $3 \mathrm{~h}$. In order to compare the output of the models, the same methods used for the REMO model data were applied.

(3) WETTREG is an SRCM developed by MeteoResearch and Climate and Environment Consulting Potsdam GmbH (Enke et al. 2006, Spekat et al. 2007). A combination of a statistical weather generator and the global climate model ECHAM5 is used to create a time series for climate stations. For each decade a typical year is calculated 200 times. The data are available through the Federal Environmental Agency (Umweltbundesamt 2007). For the study, the records from 2 climate stations, Freiburg and Feldberg, were used (see Fig. 2). The periods are identical to that of DRCM: 1961-1990, 2021-2050 and 2071-2100. The scenarios used for the simulation runs were A1B and B1.

\subsection{Climate data}

To verify the model data, we used observation data with a complete daily time series from 1961-1990 of 2 climate stations, Freiburg and Feldberg, operated by the German Weather Service (DWD). The Freiburg station (station ID 13667), is located in the upper Rhine area $\left(48^{\circ} \mathrm{N}, 7.83^{\circ} \mathrm{E}\right), 269 \mathrm{~m}$ above sea level (a.s.l.). The Feldberg station (station ID 1346), is located in the Black Forest $\left(47.87^{\circ} \mathrm{N}, 8^{\circ} \mathrm{E}\right), 1486 \mathrm{~m}$ a.s.l. The 2 stations were chosen to show the contrast between the southern part of the upper Rhine area and the mountainous region of the Black Forest.

\subsection{Methods}

The HI is one of the most commonly applied indicators to ascertain suitable winegrape variety for Europe (Huglin 1978). The HI is a heat summation method that is combined with a day length factor. Table 1 shows the

Table 1. Classes for the Huglin Index (HI), each with one example for a typical grape variety (Huglin 1978)

\begin{tabular}{|lc|}
\hline HI & Variety \\
\hline$<1500$ & Too cold for grape cultivation \\
$\geq 1500<1700$ & Müller-Thurgau, Pinot blanc \\
$\geq 1700<1900$ & Riesling, Lemberger \\
$\geq 1900<2100$ & Cabernet-Sauvignon, Merlot \\
$\geq 2100<2400$ & Grenache, Aramon \\
$\geq 2400$ & Warm enough for all winegrapes \\
\hline
\end{tabular}

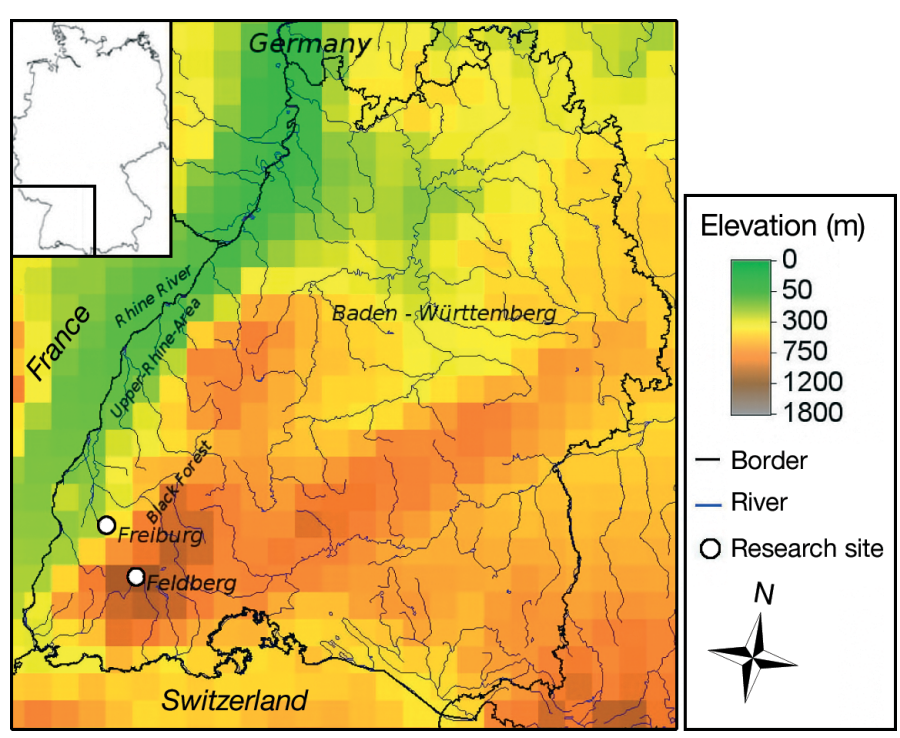

Fig. 2. Overview of the research area with the locations of the 2 research sites, Freiburg and Feldberg

HI formulation and grape variety suitability according to Huglin (1978). The equation to calculate the HI is:

$$
\mathrm{HI}=\sum_{01.04}^{30.09} \frac{\left[\left(\mathrm{T}_{\text {mean }}-10\right)+\left(\mathrm{T}_{\max }-10\right)\right]}{2} \mathrm{~d}
$$

where $\mathrm{T}_{\text {mean }}$ is the daily mean air temperature and $\mathrm{T}_{\max }$ is the daily maximum air temperature, $d$ is a length of day coefficient (Table 2). The HI is calculated for the growing period from April 1 to September 30 each year.

The model data of both DRCM were interpolated to positions of DWD climate stations for validation and comparison with the WETTREG data and the observation data of the DWD. In the horizontal direction, an inverse distance weighted interpolation using the 4 nearest grid points was applied. In the vertical direction, the air temperature was approximated from the inverse distance weighted interpolated model height to the height of the DWD climate stations by using the saturated adiabatic lapse rate.

Table 2. Coefficient $d$ for the length of day by latitude for the Huglin Index (Huglin 1978)

\begin{tabular}{|lc|}
\hline Latitude & $\mathrm{d}$ \\
\hline$\leq 40^{\circ} 00^{\prime}$ & 1.00 \\
$40^{\circ} 01^{\prime}-42^{\circ}$ & 1.02 \\
$42^{\circ} 01^{\prime}-44^{\circ}$ & 1.03 \\
$44^{\circ} 01^{\prime}-46^{\circ}$ & 1.04 \\
$46^{\circ} 01^{\prime}-48^{\circ}$ & 1.05 \\
$48^{\circ} 01^{\prime}-50^{\circ}$ & 1.06 \\
\hline
\end{tabular}




\section{RESULTS}

To better assess the results, we first conducted a validation of the DRCM and SRCM data. Following the validation, we calculated the HI from the DRCM scenario runs for the examination area, as well as the differences over time. Finally we compared all 3 RCMs to each other at the 2 observation sites.

\subsection{Validation}

To verify the scenario model simulation runs, interpolated data of the DRCM as well as scenario data of the WETTREG model were compared with observed data at the 2 climate stations. Freiburg represents the upperRhine-area, and Feldberg the mountainous region in the Black Forest (Fig. 2). For validation, annual averaged values of daily mean and maximum air temperature data, of the time segment April 1 to September 30 from 1961-1990, were compared. The allocation of the observation data and all 3 models are shown in Fig. 3 while Table 3 shows the bias of the model median to the observed data median. The results show an underestimate of the air temperature in the scenario runs of both REMO and CCLM. REMO produced good results at the Freiburg location unlike those at the mountainous location of Feldberg, while CCLM produced better results at Feldberg than at Freiburg. The difference between the biases of mean and maximum air temperature is greater at the Feldberg location for both CCLM and REMO. The WETTREG model performed best at both sites and there were no differences in the bias values between mean and maximum air temperature.

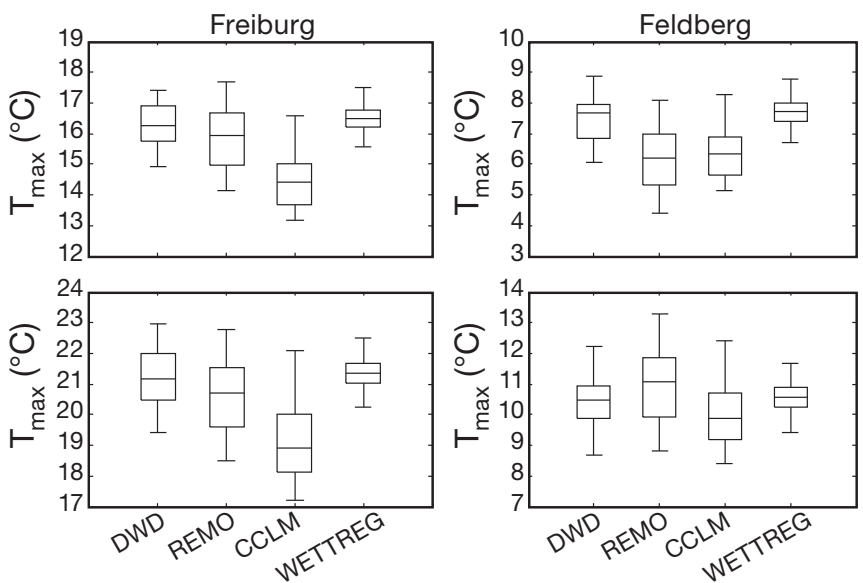

Fig. 3. Annual averaged values of the daily mean $\left(\mathrm{T}_{\text {mean }}\right)$ and maximum air temperature $\left(\mathrm{T}_{\max }\right)$ of the models REMO, CCLM and WETTREG as well as of the DWD observation data of the time segment April 1 to September 30, over the period 1961-1990. Central line: median; bottom and top of box: 25th and 75 th percentiles; whiskers: data range
Table 3. Bias of the model mean air temperature $\left(\mathrm{T}_{\text {mean }}\right)$ and maximum air temperature $\left(\mathrm{T}_{\max }\right)$ with the observed data, from April 1 to September 30 annually, averaged for 1961-1990 at the Freiburg and Feldberg climate station sites

\begin{tabular}{|lrrrr|}
\hline \multirow{2}{*}{ Model } & \multicolumn{2}{c}{ Freiburg } & \multicolumn{2}{c|}{ Feldberg } \\
& $\mathrm{T}_{\text {mean }}$ & $\mathrm{T}_{\max }$ & $\mathrm{T}_{\text {mean }}$ & $\mathrm{T}_{\max }$ \\
\hline REMO & -0.3 & -0.4 & -1.5 & 0.6 \\
CCLM & -1.9 & -2.2 & -1.3 & -0.6 \\
WETTREG & 0.2 & 0.2 & 0.1 & 0.1 \\
\hline
\end{tabular}

\subsection{Huglin Index for Baden-Württemberg}

The results of the HI values calculated from the scenario data of the 2 DRCM are as follows:

$R E M O$ scenario. The HI values calculated with data of the REMO scenario runs with SRES A1B for the 3 time periods are shown in Fig. 4a. The areas suitable for viticulture are expanding, and in 2071-2100 nearly the entire area of Baden-Württemberg will be suitable for winegrape production. Clearly visible is the upperRhine-area with suitable conditions in all 3 time periods, the suitable winegrape variety for this region however does change. In Fig. 4b, the HI values for SRES B1 are lower than those for SRES A1B. The spatial pattern is quite the same as for SRES A1B. The HI values do change over the time periods. These changes are shown in Fig. 5a for SRES A1B as well as SRES B1. For the SRES A1B, the increase in $\mathrm{HI}$ values reaches 100 to 300 in 2021-2050 and 600 to 800 in 2071-2100. For the SRES B1, the increases are near 0 to 200 in 2021-2050 and mainly 400 to 500 in 2071-2100. All in all, the increase is very similar in the entire area of Baden-Württemberg. The main distinctions are visible between the north and the south with differences of around 100 .

CCLM scenario. The calculated HI values of the CCLM scenario runs for SRES A1B are shown in Fig. 6a. According to these values, viticulture in 19611990 was only favorable in the central upper-Rhinearea. Similar to the REMO simulations, the spatial pattern of suitable areas is expanding over the time periods but at lower values. However, the suitable winegrape varieties for the upper-Rhine-area are still changing over the 3 time periods. The increase in HI values for the SRES B1 is less broad, but similar as for the SRES A1B (Fig. 6b). The differences during 19611990 and the 2 future time periods are displayed in Fig. 5b. For the SRES A1B, the increase in HI values ranges from 200 to 300 in 2021-2050 and 700 to 900 in 2071-2100. For the SRES B1, the increase is near 0 to 200 in 2021-2050 and mainly 500 to 600 in 2071-2100. The increase in calculated HI values of CCLM scenario runs is very similar in the entire area of BadenWürttemberg. The main distinction is a difference be- 

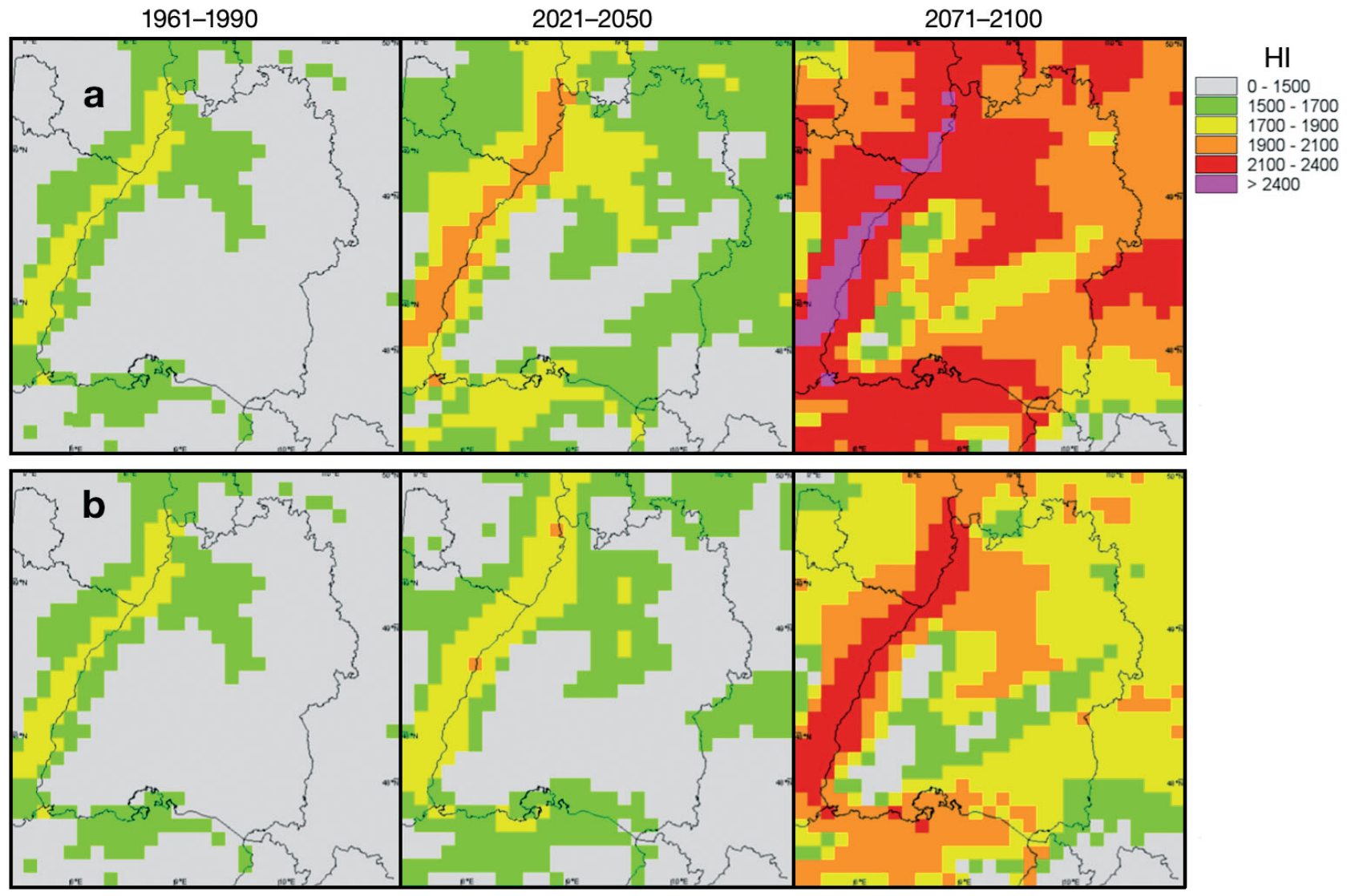

Fig. 4. Huglin Index (HI) calculated out of REMO simulations with (a) SRES A1B and (b) SRES B1, for the 3 different periods
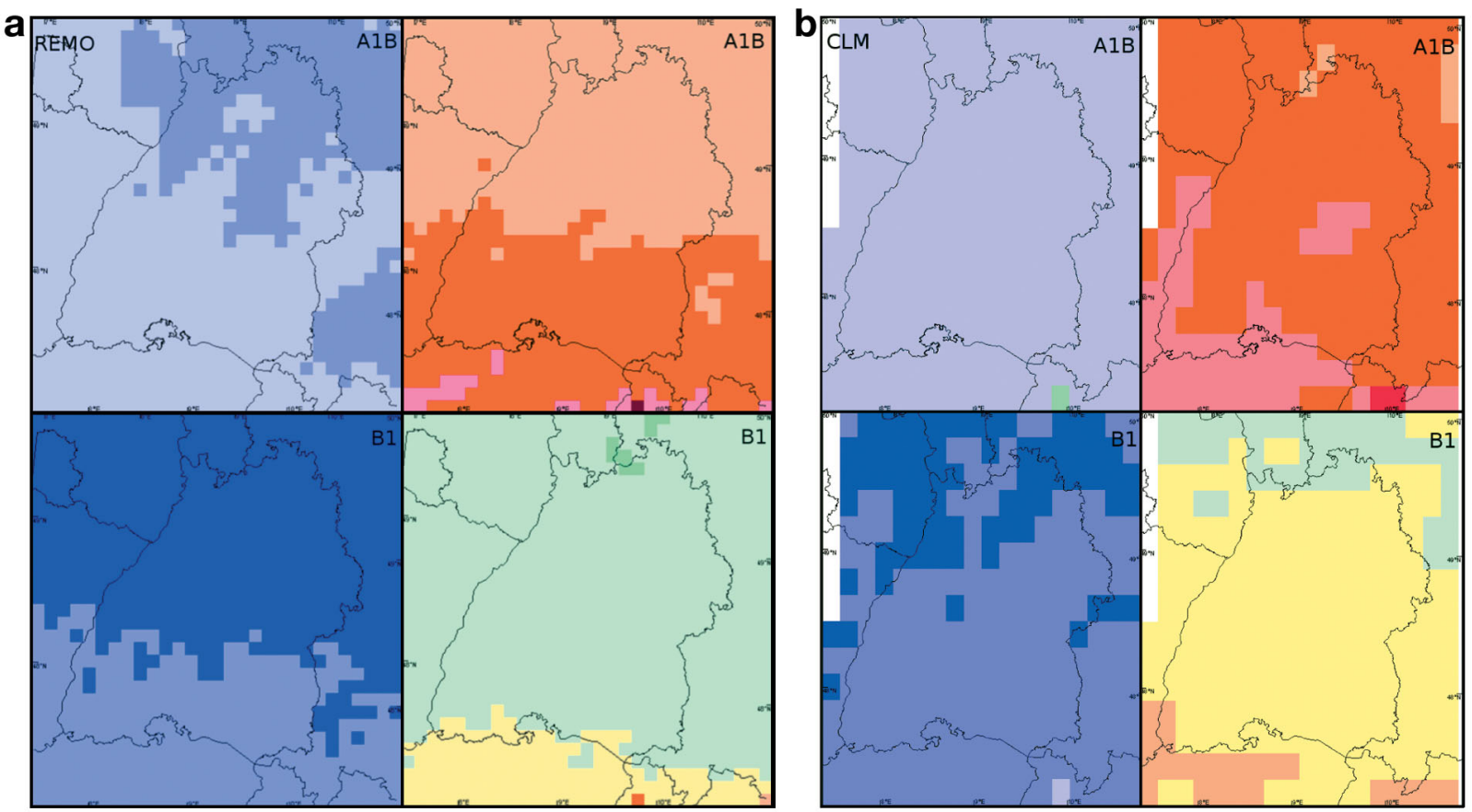

Difference

$700-800$

$800-900$

$900-1000$

$1000-1100$

1100

Fig. 5. Differences in Huglin Index (HI) values between 1961-1990 and 2021-2050 (left) and between 1961-1990 and 2071-2100 (right) for SRES A1B and B1. Calculated using (a) REMO and (b) CCLM simulations 

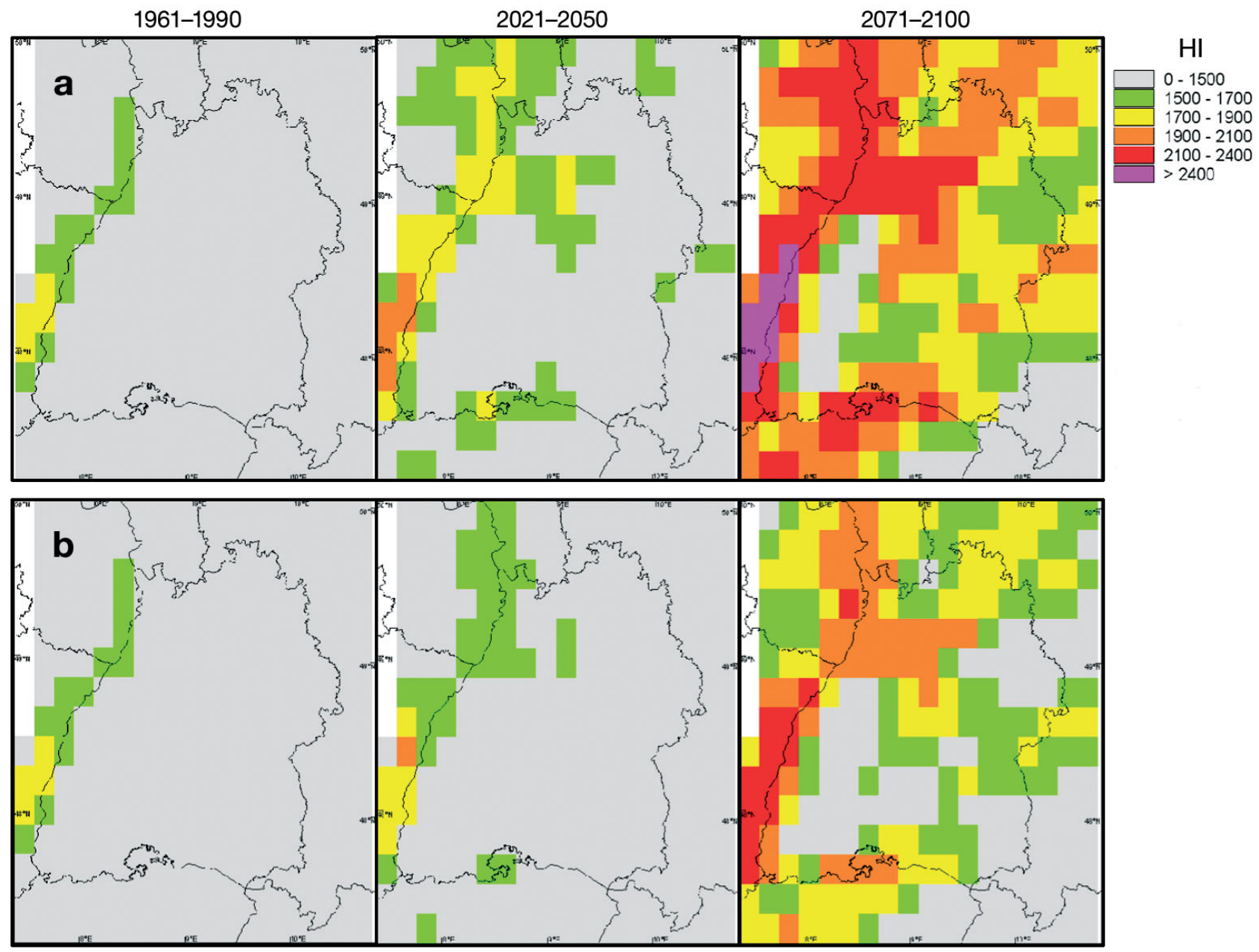

Fig. 6. Huglin Index (HI) calculated from CCLM simulations with (a) SRES A1B and (b) SRES B1, for the 3 different periods

tween the north and the south of Baden-Württemberg. For the scenario run with SRES B1 in the period of 2071-2100, values in the southern part of the upperRhine-area are slightly higher.

\subsection{Comparison}

A comparison was conducted for the calculated $\mathrm{HI}$ values of the station-based WETTREG model and interpolated values of the REMO and CCLM models at the 2 stations Freiburg and Feldberg. The results are shown in Fig. 7. The HI values for the SRES B1 are lower than those for the SRES A1B, but the spatial pattern for both scenarios are quite similar, with a smaller increase between the periods 1961-1990 and 2021-2050 than between the periods 2021-2050 and 2071-2100. This increasing pattern is identifiable in all models, independent of the SRES and the locations. In 2071-2100, the REMO model simulates the highest overall values. In Freiburg, the CCLM model shows the lowest values, while in Feldberg, the CCLM values are higher in 2071-2100 than those of the WETTREG model. Overall, the increase in HI values for WETTREG is the smallest of the 3 models at both locations.

\section{DISCUSSION AND CONCLUSIONS}

The validation shows that the WETTREG model performed best out of all 3 models at both locations in the upper-Rhine-area and the mountainous Black Forest. This result is not surprising since both DRCMs underwent a validation step unlike the WETTREG model. The CCLM results that are constantly lower than the observations. That the CCLM is 'too cold' is a known problem also observed by Böhm et al. (2006) and Jacob et al. (2007). In a direct comparison of REMO and CCLM by Endler \& Matzarakis (2010), the CCLM was colder than the REMO model. For the REMO model, the results for Freiburg are only slightly too cold. According to Jacob et al. (2007), the REMO model tended to be too 
(a) Freiburg
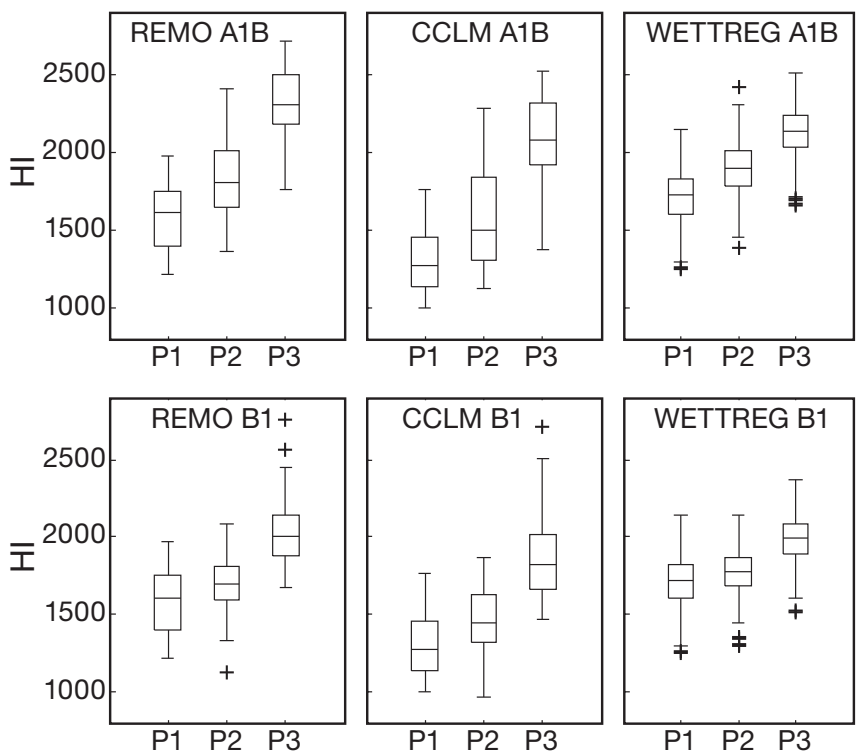

(b) Feldberg
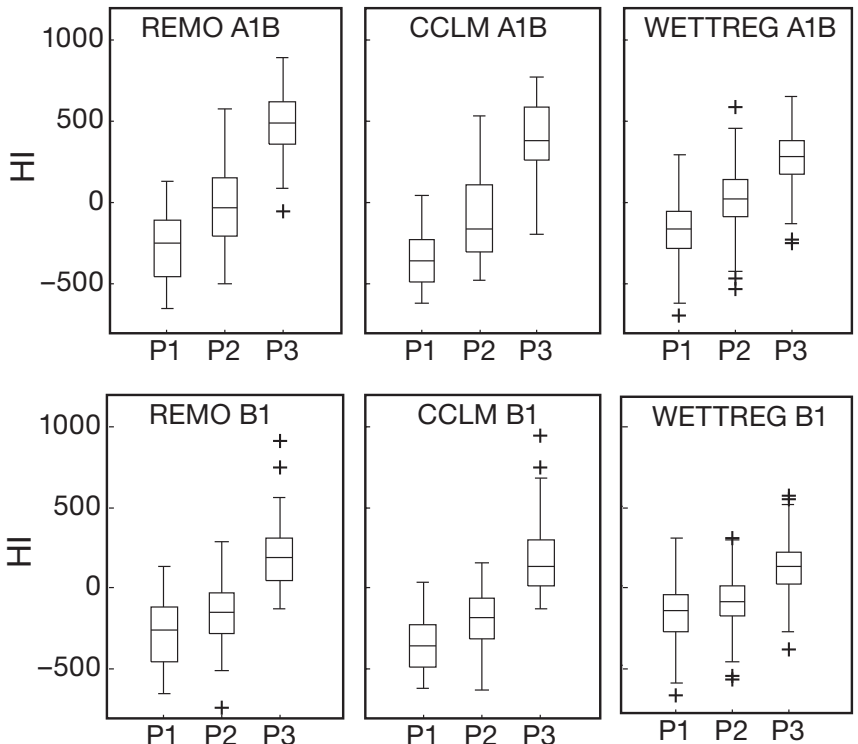

Fig. 7. Annual HI values for (a) Freiburg and (b) Feldberg, calculated from model simulations of the REMO, CCLM and WETTREG model with SRES A1B and B1. Each standard box plot shows the distribution of HI values for 3 time periods. P1: 1961-1990, P2: 2021-2050, P3: 2071-2100. Central line: median; bottom and top of box: 25th and 75th percentiles; whiskers: data range; crosses: outliers

warm rather than too cold. The difference could be a result of the different GCMs driving the REMO model, but Jacob et al. (2007) is stating that the influence of the GCM is stronger in the winter than in the summer, which would be more representative for the time period validated by the present study. Also the ECHAM5/MPIOM showed good results especially for the northern hemisphere in a study by van Ulden \& van Oldenborgh (2005), who compared different GCMs. The main reason is probably the interpolation, especially the approximation of the air temperature using the saturated adiabatic lapse rate, such that the cooling may be too strong. This estimation would be favored by the more negative mean air temperature bias of the REMO model at Feldberg, where the height difference was greater between the interpolated model orography and the height of the observation site. Larger differences in the bias values between mean and maximum air temperature are found at Feldberg. As the differences at the Freiburg location are relatively small, they are likely a result of the orographic influence, and possibly also a result of the interpolation step.

The spatial depiction of the HI values using the DRCM over the Baden-Württemberg region shows an expansion of areas suitable for viticulture for each time period. The result corresponds with the results of Stock (2005) using an SRCM. Therefore an expansion of the suitable area for viticulture in Baden-Württemberg is now simulated by at least $3 \mathrm{RCMs}$, both dynamical models as well as a statistical model. The WETTREG results at both locations also show the same pattern. At both locations, all 3 models used in the study show different values for the HI, but there is always an increase, with a particularly high increase between 2021-2050 and 2071-2100.

The development of the HI values indicates that the suitable winegrape varieties will change for the upperRhine-area, which is an important area for viticulture today. Considering that the observed increase in air temperature will be higher in the future, the pressure on winegrape growers to adapt to the changing climatic situation will also increase. The HI value increase is similarly strong for the whole state of BadenWürttemberg, with a small north-south gradient that has higher values in the south. This increase appears to be little affected by the orographical structure of Baden-Württemberg. The only exception was simulated by the CCLM model, giving a slightly stronger increase in the southern upper Rhine area than in other areas of the same latitude. This may be because the DRCM orography is less mountainous, but the increase of the HI values by the WETTREG model was also very similar at both locations.

The increase of the HI values over the 3 time periods is lower for the WETTREG model than for the DRCM. As a result of this, the CCLM model simulated even higher values than the WETTREG model in 2071-2100 at Feldberg. This occurrence is quite surprising considering that the validation of the CCLM model showed values that were too cold for both locations. The increase in temperature in the scenario model simulation runs of the CCLM model must be higher com- 
pared to those of the WETTREG model, at least in the summer months, during which the $\mathrm{HI}$ is calculated. Of the 3 models, the WETTREG results change the least.

The expansion of suitable areas may be a positive result for viticulture, but HI values $>1500$ do not necessarily mean that the new area is completely appropriate for winegrapes. The HI only considers air temperature and latitude; other parameters such as the type of soil, different hillside orientations and shadowing effects are not included. The $\mathrm{HI}$ also does not include many meteorological or hydrological parameters such as radiation or precipitation. Furthermore, the common method of using annual sums makes it impossible to consider individual weather events, which can heighten the stress of the plants. For example, the HI would be of little use for a study like White et al. (2006) where a future decrease in the production of high quality wines was estimated, caused by an increase in the number of extreme hot days during the growing season in the USA.

The emission scenarios used for this work are also noteworthy. It is possible that the scenarios B1 and even $\mathrm{A} 1 \mathrm{~B}$ are too moderate to describe the development of future emissions, especially since the recent Climate Conference in Copenhagen did not result in any significant agreements on $\mathrm{CO}_{2}$ emission reductions (UN Climate Change Conference 2009). The expected rise in atmospheric $\mathrm{CO}_{2}$ may be an advantage for viticulture. The studies of Bindi et al. (2001) and Moutinho-Pereira et al. (2009) show that an increased $\mathrm{CO}_{2}$ supply stimulated grapevine photosynthesis and yield. And the studies of Bindi et al. (2001) and Gonçalves et al. (2009) do not show negative effects on grape quality from an increased $\mathrm{CO}_{2}$ supply.

As a single climate index, the HI may not be the best method to conduct research about future changes in viticulture. However, in order to cover all the important parameters, like the occurrence of diseases and pests, a single index would become very complex and difficult to apply. The HI is well known, easy to apply and to compare. For the present study, the HI was a suitable method to investigate the future of viticulture especially for the area of Baden-Württemberg using RCM data. The HI may not be the best choice for research of a similar type outside of Europe because it was designed for Europe and may not be suitable for other regions. For this research, we choose 1961-1990 as the reference time period for the present time. By using a standard reference period, the results can be compared with other studies. By choosing a more recent time period, it is also possible to get a more accurate picture of the present climatic state. Overall we suggest combining the $\mathrm{HI}$ with other indices for future research in Europe, which was also suggested by Tonietto \& Carbonneau (2004).
Acknowledgements. The present study was financially supported by a grant from the Ministry of Science and Arts (MWK) of the Federal State of Baden-Württemberg. We also thank Dr. Hanns-Heinz Kassemeyer and Gottfried Bleyer of the Staatliches Weinbauinstitut Freiburg for their advice regarding viticulture.

\section{LITERATURE CITED}

Battaglini A, Barbeau G, Bindi M, Badeck FW (2009) European winegrowers' perceptions of climate change impact and options for adaptation. Reg Environ Change 9:61-73

> Bindi M, Fibbi L, Miglietta F (2001) Free air $\mathrm{CO}_{2}$ enrichment (FACE) of grapevine (Vitis vinifera L.). II. Growth and quality of grape and wine in response to elevated $\mathrm{CO}_{2}$ concentrations. Eur J Agron 14:145-155

BMELV (2007): Agrarpolitischer Bericht der Bundesregierung. Statistik und Berichte des Bundesministerium für Ernährung, Landwirtschaft und Verbraucherschutz. www.bmelv-statistik.de/de/service/archiv-agrarberichte/ agrarbericht-2007/

Böhm U, Kücken M, Ahrens W, Block A and others (2005) CLM - the climate version of LM: brief description and long-term applications. COSMO Newsl, 6:225-235

Duchêne E, Schneider C (2005) Grapevine and climatic changes: a glance at the situation in Alsace. Agron Sustain Dev 25:93-99

> Duchêne E, Huard F, Dumas V, Schneider C, Merdinoglu D (2010) The challenge of adapting grapevine varieties to climate change. Clim Res 41:193-204

Endler C, Matzarakis A (2010) Analysis of high-resolution simulations for the Black Forest region from a point of view of tourism climatology - a comparison between 2 regional climate models (REMO and CLM). Theor Appl Climatol

Enke W, Spekat A, Kreienkamp F (2006) Neuentwicklung von regional hoch aufgelösten Wetterlagen für Deutschland und Bereitstellung regionaler Klimaszenarien mit dem Regionalisierungsmodell WETTREG 2005 auf der Basis von globalen Klimasimulationen mit ECHAM5/MPIOM T63L31 2010 bis 2100 für die SRES Szenarien B1, A1B und A2. Zwischenbericht: Szenario A2. Forschungsbericht, Meteo-Research, Potsdam

Gonçalves B, Falco V, Moutinho-Pereira J, Bacelar E, Peixoto F, Correia C (2009) Effects of elevated $\mathrm{CO}_{2}$ on grapevine (Vitis vinifera L.): volatile composition, phenolic content, and in vitro antioxidant activity of red wine. J Agric Food Chem 57:265-273

Hagemann S, Arpe K, Bengtsson L (2005) Validation of the hydrological cycle of ERA40. In: ECMWF ERA-40 Project Report Series, No. 24. European Centre for MediumRange Weather Forecasts, Reading, UK

Hall A, Jones GV (2009) Effect of potential atmospheric warming on temperature-based indices describing Australian winegrape growing conditions. Aust J Grape Wine Res 15:97-119

Huglin P (1978) Nouveau mode d'évaluation des possibilités héliothermiques d'un milieu viticole. C R Acad Agric France 64:1117-1126

IPCC (Intergovernmental Panel on Climate Change) (2007) Summary for policymakers. In: Climate change 2007: the physical science basis. Contribution of Working Group I to the Fourth Assessment Report of the Intergovernmental Panel on Climate Change. IPCC, Cambridge University Press, Cambridge

> Jacob D, Podzun R (1997) Sensitivity studies with the regional climate model REMO. Meteorol Atmos Phys 63:119-129 
Jacob D, Bäring L, Christensen OB, Christensen JH and others (2007) An inter-comparison of regional climate models for Europe: model performance in present-day climate. Clim Change 81:31-52

Jones GV (2005) Climate change in the western United States grape growing regions. Acta Hortic 689:41-60

Jones GV, Davis RE (2000) Climate influences on grapevine phenology, grape composition, and wine production and quality for Bordeaux, France. Am J Enol Vitic 51:249-261

Jones GV, White MA, Cooper OR, Storchmann K (2005) Climate change and global wine quality. Clim Change 73 : 319-343

Laget F, Tondut JL, Deloire A, Kelly MT (2008) Climate trends in a specific Mediterranean viticultural area between 1950 and 2006. J Int Sci Vigne Vin 42:113-123

Maracchi G, Sirotenko O, Bindi M (2005) Impacts of present and future climate variability on agriculture and forestry in the temperate regions: Europe. Clim Change 70:117-135

Mariani L, Parisi S, Failla O, Cola G, Zoia G, Bonardi L (2009) A long time series of harvest dates for Grapevine. Ital $\mathrm{J}$ Agrometeorol 1:7-16

Marsland SJ, Haak H, Jungclaus HJ, Latif M, Röske F (2003) The Max-Planck-Institute global ocean/sea ice model with orthogonal curvilinear coordinates. Ocean Model 5:91-127

Moutinho-Pereira J, Goncalves B, Bacelar E, Cunha JB, Coutinho J, Correia CM (2009) Effects of elevated $\mathrm{CO}_{2}$ on grapevine (Vitis vinifera L.): physiological and yield attributes. Vitis - J Grapevine Res 48:159-165

Petgen M (2007) Reaktion der Reben auf den Klimawandel. Schweiz Z Obst-Weinbau 9:6-9

Roeckner E, Brokopf R, Esch M, Giorgetta M and others (2006) Sensitivity of simulated climate to horizontal and vertical resolution in the ECHAM5 atmosphere model. J Clim 19:3771-3791

Schultz HR (2000) Climate change and viticulture: a European perspective on climatology, carbon dioxide and UVB effects. Aust J Grape Wine Res 6:2-12

Schultz HR, Hoppmann D, Hofmann M (2005) Der Einfluss klimatischer Veränderungen auf die phänologische Entwicklung der Rebe, der Sorteneignung sowie Mostgewicht und Säurestruktur der Trauben. Beitrag zum Integrierten Klimaschutzprogramm des Landes Hessen. Projektbericht (InKlim 2012) des Fachgebiets Weinbau der Forschungsanstalt, Geisenheim

Spekat A, Enke W, Kreienkamp F (2007) Neuentwicklung von regional hoch aufgelösten Wetterlagen für Deutschland und Bereitstellung regionaler Klimaszenarios auf der Basis von globalen Klimasimulationen mit dem Regionalisierungsmodell WETTREG auf der Basis von globalen Klimasimulationen mit ECHAM5/MPI-OM T63L31 2010 bis 2100 für die SRES-Szenarios B1, A1B und A2. Endbericht, Umweltbundesamt, Dessau. Available at: www.umweltdaten. de/publikationen/fpdf-1/3133.pdf

Statistisches Bundesamt (2008) Land- und Forstwirtschaft,

Editorial responsibility: Gerd Esser,

Gießen, Germany
Fischerei. Landwirtschaftliche Bodennutzung: Rebflächen. Fachserie 3 Reihe 3.1.5. Statistisches Bundesamt, Wiesbaden. Available at: www.deutsche-winzergenossen schaften.de/inhalte/statistiken/Rebflaechen2008-statis tisches-bundesamt.pdf

SLBW (Statistisches Landesamt Baden-Württemberg) (2010) Landwirtschaftlich genutzte Fläche in Baden-Württemberg seit 1979 nach Hauptnutzungs- und Kulturarten. Statistisches Landesamt Baden-Württemberg, Stuttgart. Available at: www.statistik-bw.de/Landwirtschaft/Landes daten/LRt0702.asp

> Steppeler J, Doms G, Schättler U, Bitzer HW, Gassmann A, Damrath U, Gregoric G (2003) Meso-gamma scale forecasts using the non-hydrostatic model LM. Meteorol Atmos Phys 82:75-96

Stock M (2005) KLARA: Klimawandel-Auswirkungen, Risiken, Anpassung. PIK Report No. 99. Potsdam Institute for Climate Research, Potsdam. Available at: www.lubw. baden-wuerttemberg.de/servlet/is/14503/informations system_klara_bericht_ohne_zusatzmaterial.pdf?command =downloadContent\&filename=informationssystem_klara_ bericht_ohne_zusatzmaterial.pdf

Tonietto J, Carbonneau A (2004) A multicriteria climatic classification system for grape-growing regions worldwide. Agric For Meteorol 124:81-97

UMPIM (Umweltbundesamt und Max-Planck-Institut für Meteorologie) (2006) Künftige Klimaänderungen in Deutschland-Regionale Projektionen für das 21. Jahrhundert. Hintergrundpapier, Umweltbundesamt, Dessau. Available at: www.umweltbundesamt.de/uba-info-medien/dateien/ 3552.htm

Umweltbundesamt (2007) Regional climate changes: Recent findings; WETTREG: a statistical regionalization model. Hintergrundpapier, Umweltbundesamt, Dessau. Available at: www.umweltbundesamt.de/uba-info-medien/mysql_ medien.php?anfrage $=$ Kennummer $\&$ Suchwort $=3543$

UN Climate Change Conference (2009) Copenhagen Accord. COP15. Available at: www.denmark.dk/NR/rdonlyres/ C41B62AB-4688-4ACE-BB7B-F6D2C8AAEC20/0/copen hagen_accord.pdf

> van Ulden AP, van Oldenborgh GJ (2005) Large-scale atmospheric circulation biases and changes in global climate model simulations and their importance for climate change in Central Europe. Atmos Chem Phys Discuss 5:7415-7455

Webb LB, Whetton PH, Barlow EWR (2007) Modelled impact of future climate change on the phenology of winegrapes in Australia. Aust J Grape Wine Res 13:165-175

White MA, Diffenbaugh NS, Jones GV, Pal JS, Giorgi F (2006) Extreme heat reduces and shifts United States premium wine production in the 21st century. Proc Natl Acad Sci USA 103:11217-11222

Will A, Keuler K, Block A (2006) The Climate Local Modelevaluation results and recent developments. TerraFLOPS Newsletter 8:2-3

Submitted: June 28, 2010; Accepted: February 8, 2011 Proofs received from author(s): Mary 22, 2011 